\title{
SÖZCÜK BİRIMLERIN ÜSLUP OLUŞUMUNA KATKISI I
}

\section{İbrahim KARAHANCI*}

\author{
Geliș Tarihi: Kasım, 2016
}

Kabul Tarihi: Aralık, 2016

\section{$\ddot{O} z$}

Bilimsel bir araştırma için vazgeçilmez olan nesnellik, akademik üslup çalışmalarını yakından ilgilendirmektedir. Dil bilimi, sistemli inceleme düzlem ve yöntemleriyle bu nesnelliği oluşturabilir. Belirli sıklık, dağılım ve birleşimler sonucunda oluşan üslup, özellikle sözcük ve cümle düzeyinde belirginleşmektedir. Bu dil birimleri, dilin mevcut olanakları içinde tercihe açıklık ve seçmeli dil değişkenliği göstermesi açısından zengin malzeme içeriğine sahiptir ve eserde yansıtılan özgün yapıyı -üslubu- doğrudan etkilemektedirler. Sözcük bilgisinin alt inceleme birimlerinden adlar ve sıfatlar, yaygın kullanım alanlarıyla önemli üslup belirleyicileri olarak öne çıkmaktadır. Adlarda özel / cins, tekil / çoğul / topluluk, soyut / somut / işoluş; sıfatlarda niteleme ve belirtme (gösterme) özellikleri işlevsel ve kategorik inceleme alanları oluştururlar. Bunların metin bağlamında değerlendirilip sayısal verilerin somut aracılıklarıyla yorumlanması kapsamlı üslup tasviri için önemlidir.

Anahtar Sözcükler: Üslup, dil, nesnellik, üslup oluşumu, ad, sıfat.

\section{THE CONTRIBUTION OF WORD UNITS TO STYLIZATION I}

\begin{abstract}
The objectivity that is indispensable for a scientific research is closely related to academic style studies. Linguistics, with its systematic levels and methods can create this objectivity. The style that occurs as a result of certain frequencies, distributions and combinations become especially evident at the level of words and sentences. These language units have rich material content in terms of its preference for openness and selective language variability within the available possibilities of language, and directly influencing the originality of the author's work, style. Nouns and adjectives of sub-study units of lexicology stand out as important stylists with their widespread use. The features of nouns proper / common, singular / plural, collective, abstract / concrete, action-process; of adjectives qualification and assertion (representation) form functional and categorical study areas. It is important for the comprehensive stylistic description that these are interpreted in the context of the text and interpreted by concrete means of numerical data.
\end{abstract}

Keywords: Style, language, objectivity, stylization, noun, adjective.

\section{Giriş}

Genel bir bakışla toplumsal kodlamalarla oluşan dil ve bireysel dil tercihleri içeren üslup arasında kanıtlanabilir bilimsel ilişki kurma konusu, uzun yıllardır araştırmacıların ilgisini

\footnotetext{
*Arş. Gör.; Uludağ Üniversitesi, Fen-Edebiyat Fakültesi, Türk Dili ve Edebiyatı Bölümü, ikarahanci@uludag.edu.tr.
} 
çekmektedir. Kendi başına yöntemleri, terim hazinesi, kuramları $v b$. bulunan sistemli dil incelemeleri, elde ettiği bulguları akademik üslup çalışmalarında kullanarak, öznel değerlendirmelere açık olan bu alana nesnel bakış açıları kazandırabilmektedir. Bu konuda Widdowson'un, “üslup biliminin dil bilimi ve edebiyat bilimi arasında bağlantı kurduğunu, edebiyat eserlerindeki dil kullanımı ve örüntülerinin dil bilimine dayanan üslup tasvirleriyle daha nesnel bir biçimde belirlenebileceği” şeklindeki görüşü önemlidir (Ülsever, 2005: 331). Thornborrow ve Wareing ise üslup biliminin yoruma yer veren kişisel çözümleme yöntemleri yerine gözlemlenebilir olgular, metni oluşturan dil ve bu dil ögelerini yorumlayabilecek "bilimsel" bir disipline, yani dil bilimine sırtını dayaması gerektiğini söyler (Sarıbaş, 2001: 82). Edebiyat araştırması / eleştirisiyle dil biliminin kesişme noktasında bulunan bu yaklaşım, birbirine sıkı sıkıya bağlı bu iki disiplinin en temel ortak çalışma alanlarından biri olarak değerlendirilebilir.

Üslubu dil kullanımının özel bir bileşeni olarak gören Yıldız, dil kullanımındaki işlev ve biçimlerin üslup incelemesinin konusunu teşkil ettiğini ileri sürmektedir. Araştırmacı, bu işlev ve biçim araçlarından sadece anlambilimsel olanaklar içinde değişken olanların üslubu meydana getirdiğini, bu değişkenlerin hepsinin değil seçmeli olanların üslup özelliği taşıdıklarını söyler. Bir başka deyişle, sözcük ve dil bilgisi düzleminde eş anlamlılık gösteren değişken ve sabit araçlar içerisinden üslup açısından önemli olanlar seçilme imkânı olanlardır (Yıldız, 2003: 572573). İşte bu seçmeli değişkenlerin biçimsel ve işlevsel yüklerinin belirlenmesinde dil bilgisinin ses bilgisi, biçim bilgisi, sözcük bilgisi, söz dizimi, anlam bilgisi, metin bilgisi $v b$. alt alanları sistemli ve kategorik bir inceleme düzlemi oluştururlar. Bu aşamada dilbilgisel parçalara ayrılan incelemeye esas metin, her bir düzlemin sağladığı olanaklar içerisinde yapısal bütünlükle üslup incelemesine tabi tutulur ve böylece üslup özellikleri belirlenir. Geriye yalnızca üslup özelliği taşıyan seçmeli dil değişkenlerinin tasvir edilerek yorumlanması kalır.

Üslup kavramına, "zihinde var olan tercihe açık mevcut dil olanaklarından bilinçli / bilinçsiz olarak seçilen dil birimlerinin / dilsel özelliklerin kişiye özgü kullanımının yoğunlaşmasından doğan özgün bir yapı" şeklinde yaklaşan bu çalışmada, özellikle sözcük ve cümle birimlerinin üslup oluşumunda etkin rol oynadıkları düşünülmektedir. Bu dil birimleri, dilin mevcut olanakları içinde tercihe açıklık ve seçmeli dil değişkenliği açısından zengin malzeme içeriğine sahip olmakla birlikte hem kendi aralarındaki hem de birbirleriyle olan sık1 ilişkiyle yazarın eserinde yansıttığı özgün yapıyı -üslubu- doğrudan etkilemektedirler.

Metin kurgusunda çeşitli görevlerle donatılan sözcükler, kendi dilbilgisel kategorileri içinde anlam ve görevlerine göre özel sınıflandırmalara tabi tutulurlar. Örneğin adlar soyut / somut / iş-oluş, özel / cins, tekil / çoğul / topluluk gibi alt özellikler barındırırlar. Aynı şekilde, 
slfatlar niteleme ve belirtme; zarflar durum, zaman, nicelik, nitelik $v b$. işlev esaslı alt kategorilere ayrılırlar. Okuyucu üzerinde etki bırakarak vericinin kurmak istediği anlam dünyasına hizmet eden bu dil birimlerinin sıklık, dağılım ve birleşimleri, alımlama sürecinde zihinde bazı çağrışımların yoğunlaşmasına, aktarılmak istenen bilgi ve duyguların somutlaşmasına yol açarlar.

Bir üslup belirleyici unsur olarak sözcük, çeşitli üslup inceleme yöntemlerinde kendine yer bulmuştur. Ullmann üslup incelemesindeki üçlü düzlemden birini "sözcük üslubu"na ayırır. Michel, Ullmann'la aynı görüşleri paylaştığı ve temelde değişiklik yapmadan onun sistemini ayrıntılı hâle getirdiği sıralamasında "sözcük ögeleri”ni 9 alt öbeğe ayırır: anlam-kavram boyutu, anlam-anlatım boyutu, tarih boyutu, yöresel boyut, sosyal boyut, uzmanlık dili boyutu, yabancı dil boyutu, sözcük yapımı boyutu, deyimler boyutu (Yıldız, 2003: 577). Leech ve Short, üslup incelemesinde sözlüksel kategoriyle ilgili bulgular toplanırken sözcük tercihinin nasıl farklı anlamlar içerdiği yargısına varmanın anlamsal bir çalışma yapmak demek olduğunu ileri sürerek “sözlüksek kategori”nin önemine dikkat çeker (Sarıbaş, 2001: 85). Bunlara ek olarak Börekçi ve Tepeli (1996), Alagözlü (2005), Güney (2013), Gündoğdu (2012) ve Bulak (2016) da uygulamalı üslup çalışmalarında sözcük birimlerine yer vermişlerdir.

\section{Araştırmanın Amacı ve Soruları}

Kuşkusuz üslup belirleyici unsur olarak sadece sözcüklere bağlı kalınması kapsamlı bir üslup incelemesi için yeterli değildir. Ancak oldukça karmaşık ve sıkı ilişkilerin söz konusu olduğu üslup belirleme çalışmalarında her inceleme biriminin kendi alt kategorileri içinde ayrıntılı bir biçimde ele alınması, kapsamlı bir üslup tasvirine ve yorumuna ulaşmada büyük kolaylıklar sağlayabilir. Konunun çok yönlülüğü, dil ve üsluba sistemli bir yapı olarak bakan bir araştırma için her birimi tek tek bütün yönleriyle ele almayı zorunlu kılmaktadır. Eldeki çalışmanın varmak istediği esas nokta, elde edilecek bulgular aracilığıyla sözcük birimlerin hem dilin işletilmesinde hem de üslup oluşumunda sergiledikleri etkin rolleri göstermeye olanak tanıyacaktır.

Metnin üslubu belirlenirken dilbilgisel sınıflandırmaların zorunlu kıldığı tüm niteliklere eğilmek gereksiz bir işlemdir. Burada önemli olan yazarın öne çıkardığı niteliğin metnin anlam yönüne katkısıdır. Doğal olarak yazar, adın pek çok türünden yararlanacaktır ancak dilin doğasından getirdiği biçimsel zorunluluklar, kişisel seçim olanağı sunmadığı için üsluba da etki edemeyecektir. Sözgelimi; yalın, türemiş, bileşik biçiminde üçe ayrılarak incelenen adların biçimsel sınıflandırması, metnin bütününe anlamsal vurgu yapmadıkları ve seçmeli dil değişkenliği sergilemediği için üslup malzemesi içinde değerlendirilmemelidir. Ancak soyut ve 
somutluk, tekil ve çoğulluk, özellik ve cinslik doğrudan / dolaylı olarak seçime bağlıdır, çoğu zaman dilsel zorunluluklara dayanmayan anlamsal bütün oluşturmaya eğilimli özelliklerdir.

$\mathrm{Bu}$ düşüncelerden hareketle çalışmada şu sorulara yanıtlar aranmaya çalış1lacaktır:

1. Yazarın kişisel dil kullanımı / üslubu belirlenirken adlar ve sıfatların hangi özelliklerine dikkat edilmelidir?

2. Adlarda özellik ve cinslik seçiminin yazarın üslubuna katkısı nedir?

3. Cins adlar üslup açısından nasıl incelenebilir? Birtakım kavram alanları altında toplanan cins adların metnin anlatım bütününde oluşturdukları etkiler nelerdir?

4. Adların somut / soyut / iş-oluş ve tekil / çoğul / topluluk özelliklerinin üslup açısından değeri nasıl belirlenebilir?

5. Yazarın sıfat seçimi nasıldır? Ne tür sıfatları daha çok seçmiştir ve bunun üslup oluşumuna katkısı nelerdir?

6. Yazar kullandığı adlar ve sıfatlar arasında metnin anlatım bütününü oluşturacak bir birliktelik sağlanmış mıdır? Bu dil birimleri aracılığıyla okuyucunun algı dünyasına nasıl iletiler gönderilmiştir?

\section{Yöntem}

Bu çalışmada Ahmet Ümit'in Şeytan Ayrıntıda Gizlidir adlı kitabının 79-95. sayfaları arasında yer alan aynı adlı öyküsündeki adlar ve sıfatların üslup oluşumuna katkısı incelenmiştir. Toplam 440 cümleden oluşan metinde sözcüklerin yüklendikleri görevleri olabildiğince hatasız bir biçimde ortaya koyabilmek için kestirilebilir ve tamamlanabilir eksiltiler hesaba katılmıştır ${ }^{1}$. Daha sonra cümleler tek tek irdelenip adlar ve sıfatlar, metin bağlamı ve geçtiği yerde yazarın onlara yüklediği görev göz önünde bulundurularak belirlenmiştir². İlgili dil birimlerinin üstlendikleri görevlerin belirlenmesinde, Üstünova'nın dikkat çektiği "sözcük türü - görev adı" ayrımı göz önünde bulundurulmuştur. Araştırmacı, dildeki bütün sözcüklerin $a d$ ve eylem olmak üzere iki türü bulunduğu, ad soylu sözcüklerin dilde birbirinden farklı görevler üstlendiği, bunu da bağlandıkları dil birimlerinin görev adlarının belirlediğini ileri sürer. Türkçede ad türündeki sözcüklerin $a d$, sıfat, zarf, zamir, edat, bağlaç ve ünlem; eylem türündeki sözcüklerinse sadece eylem görevini yüklendiğini belirten

\footnotetext{
${ }^{1}$ Dilde eksiltilerin önemi ve işlevi konusunda ayrıntılı bilgi edinmek için bakınız: Üstünova, 2011: 124-134.

2 Delice, cümle içinde kullanımsal olarak somut adların soyut, soyut adlarınsa somut bir anlamı aktarmak için kullanılabildiklerini, bu durumda ortaya sözlüksel sözcük ve cümle içinde kullanımsal olarak ikili değerlendirmelerin çıkabileceğini ifade eder (2012: 20). Dildeki her birimin birbiriyle ilişkili, kapsayıcı ve tamamlayıcı özelliği göz önünde bulundurulursa cümle içindeki kullanımsal değerlendirmeler, sadece somut / soyut adların incelenmesinde değil bütün dil ve üslup çözümleme uygulamalarında bir zorunluluktur.
}

\section{TF/Re}


Üstünova, ayrıca sözcük öbeklerinin de ad, sıfat, zarf $v b$. türde görevler alabildiğinin de gözden kaçırılmamas1 gerektiğini söyler (Üstünova, 2010: 157-162).

Aytaç, olabildiğince nesnel ölçütlerle yapılacak bir üslup incelemesinde sayısal ve istatiksel verilerin önemine dikkat çeker. Araştırmac1, bir üslup çözümleme yöntemi olarak ileri sürdüğü "Matematiksel-Niceliksel Üslup İncelemesi” ile metinde geçen herhangi bir üslup ögesinin tekrarlanma oranı tespit edilip metnin genel yorumlanma sürecine katkıda bulunulabileceğini söyler (Aytaç, 2009: 87). Sarıbaş da nicel bulguları olmayan ve somut kanıtlarla desteklenmeyen üslup değerlendirmelerinin, eksik ve öznellik sınırında kalacağı görüşündedir (Sarıbaş, 2001: 84). Eldeki makalede bu düşünceler çıkış noktası kabul edilmiş, dilbilgisel üslup araçlarının işlevsel sıklıklarının belirlenmesinde sayısal verilere başvurulmuştur.

Uygulama nesnesi olarak seçilen metnin bütün sözcük tür / görevlerinin üslup değeri açısından incelenmesi, hacmi bakımından bir makalenin sınırlarını aşacağı için çalışmanın ikiye ayrılması düşünülmüştür. İlkinde dilin genel özelliğinin doğal bir sonucu olarak metinde de yüklü malzeme veren adlar ve sıfatlar; ikincisindeyse zarflar, bağlaçlar, edatlar, ünlemler ve eylemler değerlendirilmiştir.

\section{4. İnceleme ve Bulgular}

\subsection{Adlar}

Yazarın üslubunun oluşumunda adların seçimi önemlidir. Adlar, evrendeki bütün canlı ve cansız varlıkları, duygu ve düşünceleri, durumları, bütün bunların birbirleriyle olan ilgilerini karşılayarak (Atabay vd., 2003: 25), görev türü bakımından dilin en yaygın sözcük birimini oluştururlar. Eldeki metinde de doğrulan bu bilgi, dildeki genel geçer bir kurala dayanmaktadır: "Dilde her varlığın ya da kavramın bir adının var olmasına karşın her birinin kendisine özgü bir eylemi yoktur" (Yelok, 2008: 446). Eylemlerdeki bu sınırlılık, diğer sözcük türlerinde de geçerlidir. Ancak bu durum "ad"ın üslup değeri olmadığı anlamına gelmemelidir. Aksine "ad"ın üslup belirleyici rolü vardır ve bu onun çeşitli niteliklerine göre değerlendirilmesiyle belirginleşir. Dil bilgisi kitaplarında bu nitelikler, genellikle karşıtlık ve benzerlik ilişkilerinin göz önünde bulundurulduğu değişik şekillerde sınıflandırılmıştır. Bu çalışmada metnin anlatım bütününe anlamsal etki yapan ve seçmeli dil değişkenliği sergileyen özel / cins, somut / soyut / iş-oluş, tekil / çoğul / topluluk adları işlenmiştir.

Metinde adlar, çeşitli yapılarda kullanılmıştır. Hiçbir öbeğe dâhil olmayıp kendi başlarına sistemde işletilebildikleri gibi belirtili ad tamlaması, belirtisiz ad tamlaması, sıfat tamlaması, belirtisiz sıfat tamlaması, birleşik ad öbeği, unvan öbeği, bağlama öbeği, iyelik 
öbeği, edat öbeği, mastar / ortaç öbeği ve iç cümle yapılarında da bir öbek / tamlama olarak ad görevi üstelenebilmektedirler ${ }^{3}$. Ancak bu yapılar, eldeki çalışmanın kapsamı göz önünde bulundurulduğunda özel / cins, somut / soyut / iş-oluş, tekil / çoğul / topluluk adı gibi değerlendirmelere uygun olmadıkları için incelemenin dışında tutulmuşlardır. Sözcük öbeklerinin oluşumu ve yazarın onlara yükledikleri görevlerin üslup oluşumuna katkısı daha geniş bir çalışmanın konusudur. Burada yalnızca sözcük öbeklerinin ad görevindeki bileşenleri değerlendirilecektir.

\subsection{1. Özel / Cins Adlar}

Canlı, cansız bütün varlık ve kavramları tek tek ya da cins cins karşılayarak varlık ve kavramların adları olan özel ve cins adlar, yazarın üslubunun oluşmasında önemli bir ölçüttür. Dildeki her ad, özel ya da cins niteliklerinden birini mutlaka taşımak zorundadır. Metinde dildeki genel eğilime koşut olarak cins adlara daha fazla yer verildiği görülmektedir. Toplamda 1446 adın 518'i (\% 35,8) özel, 928'si (\% 64,2) cins addır.

\subsubsection{1. Özel Adlar}

Özel adlar; varlık ve kavramları genel olarak değil de tek tek karşılayan, tam benzeri olmayan varlıkları belirtmek için onlara takılan, karşıladıkları varlıklarla aralarında gerçek bir münasebet bulunmayan, karşıladıkları varlıkları bilenlere bir anlam ifade eden etiketlerdir (Ergin, 2006: 219). Eldeki metinde özel adlar çeşitli niteliklerle kullanılmıştır. Bunların sayısal dağılımı şöyledir:

Tablo 1: Özel adların istatiksel görünümü

\begin{tabular}{|l|r|r|}
\hline Kişi adları & 470 & $\% 90$ \\
\hline Kurum, kuruluş, şirket, topluluk, iş yeri adları & 24 & $\% 4,6$ \\
\hline İnançla ilgili kavram adları & 13 & $\% 2,5$ \\
\hline Yer / yerleşim birimi adları & 9 & $\% 1,7$ \\
\hline Millet adları & 2 & $\% 0,3$ \\
\hline TOPLAM & 518 & $\% 100$ \\
\hline
\end{tabular}

Ağırlığın kişi adları üzerinde bulunduğu görülmektedir. Bu sonucun çıkmasında, her cümlenin zorunlu olarak bir yargı bir de yargıyı gerçekleştiren unsur istemesi ve bu unsurun genel olarak kişiden oluşmasının rolü büyüktür. Burada dikkat çekilmesi gereken noktalardan biri, bu kişi adlarının genellikle derin yapıda bulunması yani eksiltiye bırakılmasıdır. Öyle ki 470 kişi adından 111'i yüzey yapıda, 359'i derin yapıdadır. Ancak sadece yüzey yapıdaki adlar hesaba katılsa bile metindeki özel kişi adlarının yoğunluğu dikkat çekicidir. Canlı kahramanlara

\footnotetext{
${ }^{3}$ Metinde ad göreviyle kullanılan sözcük öbeklerinin sayısı 1189'dur. Bunların 419'u sıfat tamlaması, 280'i iç cümle, 198'i belirtili ad tamlaması, 89'u iyelik öbeği, 56's1 unvan öbeği, 44'ü belirtisiz sıfat tamlamas1, 32'si ortaç öbeği, 25'i mastar öbeği, 21'i belirtisiz ad tamlamas1, 17'i bağlama öbeği, 6'sı birleşik ad öbeği, 2'si edat öbeğidir. 
gönderme yapan özel kişi adlarının sıklıkla kullanılması, anlatımın belirginleşmesi ve yazar ile okuyucu arasındaki aktarımın kolaylaşmasını sağlamaktadır.

Abdülbaki hiç duraksamadan yanitladı. (83. s.)

“Yani kızına hiçbir şey bırakmadı mı?” diye açıkça sordu Ali. (84. s.)

Kaan gelmeden Büssra'nın otopsi sonuçlarını almıştık. (84. s.)

\subsubsection{Cins Adlar}

Cins adlar; aynı cinsten birçok varlığın herkesçe bilinen ortak adıdır. Varlık ya da kavramların dildeki aslî, genel, gerçek karşılıklarıdır (Ergin, 2006: 219). Metinde cins adlar, çok çeşitli kavram alanları oluşturacak bir sıklık ve dağılımda kullanılmıştır. Bu dağılım aşağıdaki tabloda gösterilmiştir.

Tablo 2: Cins adların istatiksel görünümü

\begin{tabular}{|l|r|r|}
\hline Belirgin bir bütünlük halinde kavram alanı oluşturmayan adlar & 247 & $\%$ 26,6 \\
\hline Mekân / yer / yön kavram alanına giren adlar & 129 & $\%$ 13,9 \\
\hline Organ / vücut bölümü kavram alanına giren adlar & 76 & $\%$ 8,1 \\
\hline Akrabalık kavram alanına giren adlar & 74 & $\%$ 7,9 \\
\hline Araç / gereç kavram alanına giren adlar & 69 & $\% 7,4$ \\
\hline Cinayet / ölüm kavram alanına giren adlar & 57 & $\%$ 6,1 \\
\hline Unvan kavram alanına giren adlar & 51 & $\%$ 5,4 \\
\hline Parasal değerler kavram alanına giren adlar & 50 & $\%$ 5,3 \\
\hline Duyulara yönelik adlar & 38 & $\% 4$ \\
\hline Duygu kavram alanına giren cins adlar & 37 & $\% 3,9$ \\
\hline Polisiye sorgulama / araştırma kavram alanına giren adlar & 36 & $\% 3,8$ \\
\hline Zaman kavram alanına giren adlar & 35 & $\% 3,7$ \\
\hline İnanç kavram alanına giren adlar & 15 & $\% 1,6$ \\
\hline Sayı kavram alanına giren adlar & 14 & $\% 1,5$ \\
\hline TOPLAM & 928 & $\% 100$ \\
\hline
\end{tabular}

Metinde belirgin bir bütünlük halinde kavram alanı oluşturmayan adlar yoğunluktadır. Canlı / cansız, genel / özel, varlık / kavram vb. çeşitli özellikte 247 (\% 26,6) ad, sözcüksel üslup değerlendirmesine malzeme verecek belirgin bir sıklığa erişememiştir. Ancak bunlar bir kenarda tutulduğunda mevcut cins adların 681'inin (\% 73,4) çeşitli kavram alanları etrafında öbeklendiği gözlenmektedir. Yazarın bunlar arasından yaptığı seçimler ile bu seçimlerin sıklığ ve dağılımı, anlatım bütününün oluşmasına ve anlamın biçimlenmesine yön vermektedir.

Mekân / yer / yön kavram alanına giren cins adların yoğun olarak kullanılması, yazarın, mekân algısına özellikle önem verdiğinin bir göstergesidir. Dilbilgisel düzlemde mekân / yer / yön bildiren dil birimleri zorunlu değil seçimlik unsurlardır. Söz konusu yoğunluk, yazarın seçme olanaklarını bu kavram alanından yana kullanarak okuyucunun zihninde mekânın belirginleşmesini öncelediğini göstermektedir. Özellikle ev, apartman, daire, kat, salon, oda, bodrum gibi herkesçe bilinen ve günlük yaşamın vazgeçilmez bir parçası olan kapalı alanlar tercih edilerek okuyucunun anlamlandırma sürecine doğrudan müdahale edilmiştir.

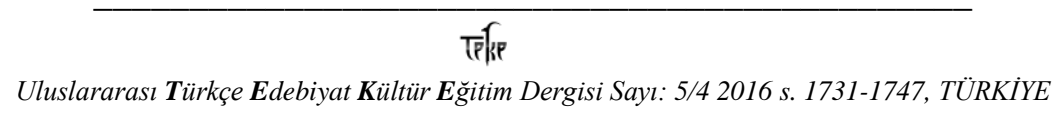


Küf, tütsü, çürümüş et karışımı bir koku evin her yanına sinmişti. (79. s.)

Aksaray'da dört katlı bir apartmanı vardı. (84. s.)

Salonun ortasındaki yıldıza bağlanmış, sonra da bıçaklanmış. (86. s.)

Yazarın insan bedeniyle ilgili cins adlara özellikle gözlemlerini aktardığı ayrıntılı betimlemelerde yer verdiği gözlenmiştir. Çeşitlilik bakımından da zengin bir söz hazinesinin yansıtıldığı organ ve vücut bölümü adları, okuyucunun gözünde her bir ayrıntının özenle ve bilinçli bir biçimde canlandırılmasını sağlamıştır. Mecaz kullanımlarına da oldukça elverişli olan bu adların tamamı, birer inceleme ve gözlem nesnesi olarak gerçek anlamlarında tercih edilmiştir. Bu veriler ışığında yazarın incelenen öyküsünde söz konusu sanatsal olanağa eğilimli göstermediği ileri sürülebilir.

Yaklaşıp baktım, saçlarında da kurumuş kan vardı. (81. s.)

Abdülbaki yüzünü sikıntıyla buruşturdu. (82. s.)

Kaan'ın açık renk gözleri şaşkınlıkla büyüdü. (86. s.)

Akrabalık adlarındaki yoğunluk, yukardaki mekân / yer / yön ile organ / vücut bölümü kavram alanına giren adlardan biraz farklı yorumlanabilir. Üslup belirleyicilikte sıklık kadar dağılım ve çeşitlilik de önemlidir. Örneğin akrabalık kavram alanına giren toplam 74 addan 52'sinin "abi” olmas1, bir bütün olarak değerlendirildiğinde sağlıklı bir yoruma olanak tanımamaktadır. Ancak “abi” adının büyük bir çoğunlukla, diğer akrabalık adlarınınsa tamamının gerçek akrabalık ilişkilerini göstermesi önemlidir. Bunların belirgin kişilere işaret etmesi, kahramanların aile ilişkilerine yoğunlaşıldığını düşündürmektedir.

Bir ay önce vefat eden Resul Abimin klzıydı. (81. s.)

Zaten ne olduysa yengemin ölümünden sonra oldu. (82. s.)

Büşra'nın tırnağındaki deri dokusu öz amcasına aitti. (95. s.)

Metinde üslup belirleyicilik sergileyen bir diğer cins ad öbeği, sözdizimsel düzlemde genellikle nesne görevini üstlenen araç / gereç adlarıdır. Nesne, geçişli eylemlerin yüklem olduğu cümlelerin zorunlu ögesidir. Yazarın bu zorunluluğu araç / gereç adlarını tercih ederek yerine getirmesi, organ ve vücut bölümü adlarında da karşılaşıldığı gibi yazarın gözlem gücünü gösteren ayrıntılı betimlemeleri akla getirmektedir.

Kaygılanıp çilingire kapıyı açtırdım. (79. s.)

Büşra'nın esyalarını arkadaki küçük odada bulduk. (92. s.)

TF̂R

Uluslararası Türkçe Edebiyat Kültür Eğitim Dergisi Sayı: 5/4 2016 s. 1731-1747, TÜRKİYE 
“Peki, ben onlara söylerim,” diyerek kapattım telefonu. (93. s.)

Cinayet / ölüm, parasal değerler ve sorgulama / araştırma kavram alanına giren adlar, daha çok okuyucuyu metnin özel konusuna, içine dâhil etmek için tercih edilmiştir. Bu cins adlara başvurularak metnin anlatım bütününün ve ana temanın bu kavramların etrafında gelişmesi sağlanmıştır. Aslında öykünün içeriğinin polisiye özelliği göstermesinin en temel dayanaklarından birini bu kavram alanlarının oluşturduğu ileri sürülebilir. Yani, "Cins adların seçiminde ve sıklığındaki özel odaklamalar, içeriğin biçimlenmesinde önemli rol oynamıştır." denebilir.

Sanki gerçek bir cinayet mahallinde değil de bir Amerikan filminin stüdyosundaymış gibiydim. (80. s.)

\section{Ceset tam bu yıldızın üzerine bağlanmıştı. (81. s.)}

Ali gitaristin adını not ederken, “Abiniz Almanya'da çalıştı̆̆ına göre epeyce bir dünyalı̆̆ olmall," diye sordum. (83. s.)

Yani iki yüz milyarlı senetlere fena halde ihtiyacı vardı. (93. s.)

Başııın altında kan izleri gördüm. (81. s.)

“Burada soruları biz sorarı,," diye, Kaan'ın ensesinde gürledi Ali. (86. s.)

\subsubsection{Somut / Soyut Adlar, İş-Oluş Adları}

Somut adların karşıladıkları kavramlar beş duyu organıyla algılanabilir. Bu tür dil göstergeleri, kendilerini oluşturan gösteren-gösterilen ilişkisinde, gösterilenleri beş duyu organıyla algılanabilen göstergelerdir (Karaağaç, 2012: 730). Soyut adlarsa görünürde madde olarak var olmayan, duyu organlarımızla kavranamayan, ancak zihnimizde var olan kavramlara ve niteliklere karşılık olan adlardır (Korkmaz, 2009: 196). Soyut kavramların görülebilir fiziksel nitelikleri bulunmadığını, ancak anlamsal özellikleriyle bilindiklerini belirten Karaağaç, alıcının daha önceki bilgileri arasında bulunuyorsa bir iletişim değerlerinin olduğunu söyler (Karaağaç, 2012: 732).

Bütün özel ve cins adlar, somut / soyutluk / iş-oluşluk açısından incelenebilir. Metinde kullanılan özel adların hemen hemen hepsi (\% 97,5) somutken, cins adların büyük bir kısmı (\% 81,7) somuttur. Özel adlardaki mevcut durum, üslup belirleyicilik konusunda malzeme vermekten uzaktır ancak cins adlardaki hem somutluk / soyutluk dağılımı hem de bunların arasındaki özel dağılımlar, yazarın kişisel dil kullanımını göstermede önemlidir. Ayrıca metinde kullanılan iş-oluş adları da oldukça az sayıdadır (7 iş-oluş adı, \% 0,7 ) ve bunlar da değerlendirme dişında tutulmuştur. 
Yukarda cins adlar değerlendirilirken duyuların kavram alanına giren sözcüklerin belirli bir sıklık oranına sahip olduğu gösterilmişti. Beş duyudan görme, işitme ve koklama duyularına ait adların öbekleşmesiyle ortaya çıkan bu sonuç, somut adların yoğunlaşmasıyla da desteklenebilir. Metindeki somut adlar, yine bu üç duyu çerçevesinde toplanmıştır. Daha çok görme duyusuna hitap edilmiş, anlatım okuyucunun zihninde görselleştirerek somutlaştırılmaya çalışı1mıştır. Ayrıca mekân / yer / yön, organ / vücut bölümü, araç / gereç kavram alanına giren adlarla bu görsellik vurgulanmıştır.

Küf, tütsü, çürümüş et karışımı bir koku evin her yanına sinmişti. (79. s.)

Masadan iskemlelere, duvardaki afişlerden pencerelerdeki perdelere, yerdeki halılara, kitap kapaklarına kadar her şey siyahtı. (80. s.)

Daha kapıdan içeri adımımızı atar atmaz kulakları tırmalayan bir müzik karşıladı bizi. (90. s.)

Soyut adlarla metinde sıkça karşılaşılmaz. Sayı ve zaman kavram alanına giren soyut adlardan ziyade anlatım bütününe doğrudan etki ederek okuyucuda olumsuz duygular uyandıran adların seçimi dikkat çekicidir. Bunlardan iğrenç, çaresizlik, gerginlik, keder, korku, panik, ciddiyet, şaşkınlık, adamcağız, şiddet, imkânsız, saygısızlık, suskunluk sözcüklerinin oluşturduğu çağrışımlar, öykünün ana temasını oluşturan "cinayet” kavramının soyut bileşenleri olarak kabul edilebilir.

Hatta çaresizliğinden onu dövmeye kalktı, bunun üzerine de Büşra evi terk etti. (83. s.)

Kaan'ın gözlerindeki korku paniğe dönüşmek üzereydi. (87. s.)

Başak daha önce sözünü ettiğim șiddet yanlısı Satanist gruplara katılmıştı. (88. s.)

Delice tarafindan ileri sürülen "cümle içinde kullanımsal olarak somut adların soyut, soyut adlarınsa somut bir anlamı aktarmak için kullanılabildikleri, bu durumda ortaya sözlüksel sözcük ve cümle içinde kullanımsal olarak ikili değerlendirmelerin çıkabileceği” (Delice, 2012: 20) şeklindeki görüş, üslup değerlendirmesi için önemlidir. Eldeki çalışmanın bütününde olduğu gibi somut / soyutluk ayrımında da sözlüksel sözcük değil cümle içindeki kullanımsal değerlendirme göz önünde bulundurulmuştur. Metnin büyük çoğunluğunda somut adlar, somut; soyut adlarsa soyut karşılıkları aktaracak biçimde doğrudan, genellikle sözlükteki ilk anlamlarında kullanılmıştır. Yani sözcükler, ortalama bir okuyucunun daha önceki bilgileri arasında bulunan ve akla ilk gelen yaygın anlamlarında bağlama sokulmuştur. İletişimin bu şekilde kurulması, bir yandan estetik kaygıların öne çıkarılmadığını gösterirken öte yandan okuyucunun anlamlandırma sürecinin hızlandırılmasına olanak tanımaktadır. Okuyucunun 
metne odaklanması, sözcüklerin günlük hayatta olduğu gibi en yaygın anlamlarında kullanılmasıyla sağlanmıştır.

\subsubsection{Tekil / Çoğul Adlar, Topluluk Adları}

Dil bilgisi kitaplarında adlarda tekillik / çoğulluk sayı kategorisiyle birlikte ele alınır. Ancak metinde kullanılan sayılar, sıfat görevini üstlendikleri için bu başlık altında yalnızca tekil ve belirsiz çokluk bildiren adlar değerlendirilmiştir.

Özel adlarda doğaları gereği tekillik / çoğulluk aranmaz. Cins adlarsa hem somut hem de soyut özelliklerine göre incelenebilir. Metinde dildeki genel eğilime koşut olarak \% 90'lık bir oranla teklik kategorisi tercih edilmiştir. Bu durumun üslup belirleyicilik açısından bir değeri yoktur. Ancak sayıları az olmakla birlikte oluşturdukları etki göz önünde bulundurulduğunda çoğul cins adların ait oldukları kavram alanları dikkat çekicidir. Toplam 93 çoğul adın 39’u (\% 41,9) organ / vücut bölümü (gözler, eller, ayaklar, saçlar, parmaklar, kulaklar, tırnaklar, kaşlar, dudaklar vb.) ve araç / gereç (afişler, pencereler, perdeler, halılar, kapaklar, mıhlar, eşyalar, parçalar, harfler, rakamlar, resimler vb.) adlarından oluşmaktadır. Burada sayısal bir çokluk ifadesi aktarılmakla birlikte özellikle bu kavram alanlarına ait adlar seçilerek ayrıntılı betimlemeler okuyucunun zihninde çoğaltılmaya çalışılmıştır. Ayrıca metinde soyut cins adların çoğullaştırılmadığını belirtmek gerekir.

Metinde topluluk adlarından yalnızca 5 yerde yararlanılarak üslup oluşumuna olanak sağlayacak bir yoğunluk oluşturulmamıştır.

\subsection{Sifatlar}

Dilde çok geniş bir kullanım alanına sahip olan sıfatlar, adları niteleyen, nasıl olduklarını gösteren ya da çeşitli yönlerden belirten sözcüklerdir (Korkmaz, 2009: 333). Sıfatlar, görevli dil birimleridir ve adlar olmadan kullanılamazlar. Adların çeşitli özelliklerini soyut bir biçimde göstermekle görevlidirler. Yapı olarak ad sözcük türünde olduğu gibi bazı öbek / tamlamalardan oluşabilirler. Metindeki toplam 443 sifattan 125'i $(\% 28,2)$ öbek / tamlamadan oluşurken 318'i $(\%$ 71,8) herhangi bir yapı birlikteliği içermez.

Dilbilgisinde kökenlerine, yapılarına ve işlevlerine göre olmak üzere üç ana başlık altında ele alınan sıfatların üslup açısından belirleyici rolü, işlevsel kullanımlarında ortaya çıkar. $\mathrm{Bu}$ çalışmanın amacına uygun bir biçimde sıfatlar, metin içinde üstlendikleri işlevlere göre sınıflandırılıp değerlendirilmişlerdir. 443 sıfattan 291'i (\% 65,6) niteleme, 152'si (\% 34,4) belirtme sıfatıdır. Aşağıda önce bu iki öbeğe ayrılmışlar, ardından oluşturdukları kavram alanları göz önünde bulundurularak yorumlanmışlardır. 


\subsubsection{Niteleme Sıfatları}

Canlı, cansız varlıkların renk, şekil, biçim, tat, koku, mesafe, huy, alışkanlık, yetenek, beceri gibi türlü türlü dış ve iç özelliklerini bildiren sıfatlardır (Korkmaz, 2009: 361). Bu çok çeşitli özellikler belirli kavram alanları altında toplanarak belli bir sıklığa erişip yazarın üslup özelliğini oluşturur. Metindeki 291 niteleme sıfatı aşağıdaki tabloda gösterildiği gibi bir sıklık örgüsü oluşturmuştur.

Tablo 3: Niteleme sıfatlarının istatiksel görünümü

\begin{tabular}{|l|r|r|}
\hline İş, oluş ve hareket bildiren sıfatlar & 65 & $\%$ 22,3 \\
\hline Mekân / zaman / kişi / nesnede bulunma bildiren sıfatlar & 52 & $\% 17,8$ \\
\hline Soyut / içe dönüklük bildiren sıfatlar & 46 & $\% 15,8$ \\
\hline Benzerlerinden ayırmakla görevli tür bildiren sıfatlar & 43 & $\% 14,7$ \\
\hline Dış görünüş, beden yapısı ve fiziksel özellik bildiren sıfatlar & 40 & $\% 13,8$ \\
\hline Karşılaştırma, derecelendirme ve benzetme bildiren sıfatlar & 25 & $\% 8,6$ \\
\hline Herhangi bir özelliğe sahip olma bildiren sıfatlar & 15 & $\%$ 5,2 \\
\hline Mekân / zamanda mesafe bildiren sıfatlar & 5 & $\% 1,8$ \\
\hline TOPLAM & 291 & $\% 100$ \\
\hline
\end{tabular}

Önce genel bir değerlendirmeyle niteleme sıfatlarının belirtme sıfatlarına göre sıkça kullanılması ele alınabilir. Niteleme sıfatlarındaki söz konusu yoğunluk metne bir öznellik kazandırmıştır. Çünkü yazar, belirtme sıfatlarına oranla niteleme sıfatlarında daha geniş bir çağrışım hazinesine sahiptir. Niteleme sıfatları aracılı̆̆ıyla metne yansıyan kişisel dokunuşlar okuyucunun hayal dünyasını genişlemesine, eserde geçenler hakkındaki bilgilerin ayrıntılanmasını sağlar.

Tabloda görüldügü gibi niteleme sıfatlarının çoğunluğunu iş, oluş ve hareket bildiren niteleme sıfatları oluşturmaktadır. Bu sıfatlar, dil bilgisinde eylemsiler kategorisinde ele alınan ortaç / ortaç öbeklerinden oluşmaktadır. Yazar, niteleme işlevini eylemin iş, oluş ve hareket bildirme özelliğinden yararlanarak gerçekleştirmeye çalışır. Aşağıda verilen örneklerde de görüleceği üzere söz konusu niteleme sıfatları, genellikle kişileri ve nesneleri (araç / gereç ve organ / vücut bölümü adları) tamlamıştır. Bu özellik, kişi ve nesnelerin hareket halinde kavranmasına yol açarak metne dinamizm ve akıcılık kazandırmıştır.

"Bilmiyorum," dedim, sonra hâlâ kapının yanında dikilen Abdülbaki'ye döndüm “Onunla en son ne zaman görüşmüştünüz?” (79. s.)

Elleri ve ayakları yana gerilerek, yere çakılmıș kalın mıhlara iplerle bağlanmıştı. (80. s.)

Bakışlarım sağ eline kaydl, rengi atmıș, soğuk parmaklarını avucum içine aldım. (81. s.)

Cins adların incelendiği bölümde yazarın mekân / yer / yön algısına ne kadar önem verdiğinden söz edilmişti. Sıfat düzleminde bu eğilimin kendini gösterdiği kavram alanı, mekân 
/ zaman / kişi / nesnede bulunma bildirmedir. Böylece yazar, cins adlarda sergilediği mekânı öne çıkarma eğilimini, sıfatlarda tamlanan / nitelenen adın bulunma işlevini vurgulayarak da göstermiştir.

\section{Kapının yanındaki elektrik düğmesine dokununca içerisi aydınlandı. (80. s.)}

Duvardaki bir posterde de Büşra’nın üzerinde öldürüldüğ̈̈ yıldızın aynısından vardı. (89-90. s.)

\section{“Tarlabașı'ndaki Black Angel Bar'a taklliyorlarmış.” (89. s.)}

Biçimsel olarak belirtisiz ad tamlamasına benzemekle birlikte işlevsel olarak onun gibi aitlik-sahiplik anlam ilişkisi kurmayan, aksine sıfatların en belirgin özelliklerinden önüne geldiği / tamladığı adı benzerlerinden ayırmakla görevli belirtisiz sıfat tamlamalarına ${ }^{4}$ metinde

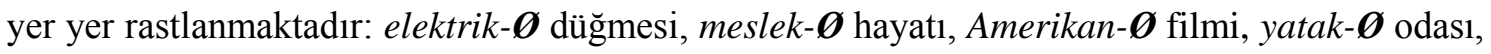
kan-Ø kanseri, tiyatro- $\boldsymbol{\varnothing}$ oyunu, not- $\boldsymbol{\varnothing}$ defteri, polis- $\boldsymbol{\varnothing}$ kimliği $v b$. Bu tür yapılarda düğmenin, kanserin, defterin, oyunun $v b$. türü / sıfat unsuru belirli bir kavram alanına odaklanmamış, anlamsal yoğunluk açısından bir üslup belirleyicilik oluşmamıştır ${ }^{5}$. Ancak yazarın betimsel anlatım çerçevesinde tamlanan unsurunu / adı niteleme gereği duyması, ayrıntıya başvurarak onu diğerlerinden ayıran tür özelliğine işaret etmesi dikkat çekicidir.

Niteleme sıfatlarında üslup açısından değer oluşturan son öbek; dış görünüş, beden yapısı ve fiziksel özellik bildiren sıfatlardır. Yazar, adları dış özellik ve fiziksel yapıları itibariyle niteleyerek okuyucunun zihinsel çağrışımlarına görsel ve duyusal sınırlar getirmiştir. Bir tür somutlaştırmanın güdüldüğü bu seçim, diğer niteleme sıfatları kadar yaygın olmasa da oluşturduğu etki göz önünde bulundurulduğunda önemsenmelidir. Çünkü bilgi ve duygunun aktarımında görsellik ve somutluğun etki gücü azımsanamayacak derecede büyüktür.

Gitarist Kaan, uzun saçlı, sakall, grubun öteki üyeleri gibi siyahlar içinde bir adamdl. (83. s.)

Uzun boyluydu, çiçekbozuğu geniș suratın koyu renk bir sakalla gizlemeye çalışıordu. (84. s.)

Büşra’nın eşyalarını arkadaki küçük odada bulduk. (92. s.)

\footnotetext{
${ }^{4}$ Üstünova; iyelik eki, belirtme işleviyle ardındaki ada bağlanıyor ve tamlama, belirtili ad tamlamasına çevrilmiyorsa belirtisiz ad tamlamasından söz edilemeyeceğini söyler. Sokullu Camii, Fatih Sultan Mehmet Bulvarı, Uluda $\breve{g}$ Üniversitesi, keçi boynuzu, ipek böceği, çocuk arabası gibi sözcük öbeklerini sıfat tamlaması saymak gerekir diyen araştırmacı, bu tür sıfat tamlamalarını diğerlerinden ayırmak için "belirtisiz sıfat tamlaması" terimini önerir. Belirtisiz sıfat tamlamalarında tamlanandaki iyelik ekinin görevi, önüne geldiği adın sahibini göstermek değil geldiği adın belirlenmesini sağlamaktır (Üstünova, 2012: 97).

${ }_{5} \mathrm{Bu}$ sözcük öbeğindeki üslup belirleyicilik, yapının bütününde aranmalıdır. Nitekim genellikle ad görevinde kullanılan belirtisiz sıfat tamlamaları, adların incelendiği bölümde değerlendirilmiş ve belirgin bir kavram alanı oluşturmadıkları görülmüştür.
} 


\subsubsection{Belirtme (Gösterme) Sıfatları}

Belirtme (gösterme) sıfatları, niteleme sıfatlarından farklı olarak varlıkları niteleme değil belirtme işlevi yüklenmiş olan sıfatlardır. Bu işlev, adları işaret etme, gösterme, sayı ve miktarını bildirme, sorma ya da belirsizliğini gösterme biçiminde karşılanır (Korkmaz, 2009: 385). Belirsizlik, işaret, sayı ve soru şeklinde dört ayrı alt başlıkta incelenen belirtme sıfatlarının metin içindeki dağılımı şöyledir:

Tablo 4: Belirtme sıfatlarının istatiksel görünümü

\begin{tabular}{|l|r|r|}
\hline Belirsizlik sıfatları & 87 & $\% 57,2$ \\
\hline İşaret sıfatları & 32 & $\% 21,1$ \\
\hline Sayı sıfatları & 31 & $\% 20,3$ \\
\hline Soru sıfatları & 2 & $\% 1,4$ \\
\hline TOPLAM & 152 & $\% 100$ \\
\hline
\end{tabular}

Belirtme sıfatlarının 87'si (\% 57,2) belirsizlik sıfatlarına aittir. Bu sonucun çıkmasında günlük dilde sıkça tercih edildiği gibi metinde de epeyce kullanılan "bir" belirsizlik sıfatıdır. Toplam 57 kez kullanılarak metinde geçen bütün sıfatlar içinde büyük bir yer edinmiştir ${ }^{6}$. Yazar herhangi bir varlığı ya da kavramı belirsiz bir şekilde nitelemek istediğinde bu sayı kökenli sözcüğe başvurmaktadır. Belirsizlik sıfatları aracılığıyla, yazar, tamlanan görevindeki adın belirginleşmesine müdahale etmemiş, okuyucunun kendi zihinsel aktivitelerini gerçekleştirebilmesi için bir serbestlik sunmuştur. Ayrıca belirsizlik sıfatlarının sıkça kullanılması, kanıtlanabilir kesinliktense muğlaklığa gönderme yapma niyetinden kaynaklanabilir.

Dokuz tanesini sayabildiğim yaralar, bıçak ya da benzeri bir aletle açılmıştı. (80. s.)

Gitarist Kaan, uzun saçll, sakall, grubun öteki üyeleri gibi siyahlar içinde bir adamdl. (83. s.)

"Hiç merak etme, yarın sana istediğin her şeyi veririm," dedi. (84. s.)

Metinde işaret ve sayı sıfatları hemen hemen aynı sıklıkta tercih edilmiştir. Evrendeki varlık ya da kavramları gösterme yoluyla belirten işaret sıfatlarının dildeki kullanımı $b u, s ̧ u, o$ dil birimleriyle sınırlıdır. Belirtilen / gösterilen adın mekân, zaman ya da düşünüşteki uzaklık derecelerine göre seçilirler. Eldeki metinde daha çok "bu" işaret sıfatı kullanılarak en yakın gösterme mesafesi öne çıkarılmıştır. Yazarın bu tutumu, bir çeşit sınırlama ve odaklama eğiliminin bir göstergesi olarak kabul edilebilir.

Sanki bu ürkütücü şekille uyum sağlayıp yıldızın bir parçası olmuştu. (81. s.)

\footnotetext{
6 "Bir" belirsizlik sıfatının yaygınlığı Yazılı Türkçenin Kelime Siklı̆̆ Sözlüğü adlı eserde ortaya konmuştur (Göz, 2003: 213).
} 
Oda toz içindeydi, anlaşılan kızına öfkelenen baba bu odaya aylardır ayak basmamıştı. (92. s.)

Ama içerisi o evdeki gibi sessiz değildi. (90. s.)

Barın sahibinden başka bir şey öğrenemedik. Ama șu kurban meselesi ilginçti. (92. s.)

Aslında birer ad olan sayı sözcükleri, metninde adların sayı değerlerini gösterme işleviyle kullanılmıştır. Genel olarak eserdeki sıfat ve ad kategorileri göz önünde bulundurulduğunda sayıların ifade ettiği niceliksel anlam değerinden çok fazla yararlanılmadığ 1 gözlenmektedir. Yine de yazar, zaman zaman nesnelerin sayısal ölçülebilirliğine başvurarak nesnel algı oluşumuna önem verdiğini belli etmektedir. Zaman ve parayla ilgili adların özellikle sayı yoluyla belirginleştirilmesi, okuyucunun zihninde sınırlar oluşmasına ve odağın söz konusu sayısal değerler üzerine çekilmesine yol açmıştır.

“当 gün önce konuşmuştum," dedi adam hüzünlü yüzünü kaplayan kırlaşmış, uzun sakalını karıştırarak. (79. s.)

Yani iki yüz milyarlık senetlere fena halde ihtiyacı vardı. (93. s.)

“Evet, Resul Abimin üzerinden çılkan yedi yüz mark bendeydi.” (84. s.)

\section{Sonuç ve Tartışma}

Akademik üslup incelemelerinin dilbilimsel araştırma yöntemlerinin sağladığ olanaklarla nesnel bir zemine yerleştirilebileceği görüşünden hareket eden bu çalışmada sözcük bilgisinin alt inceleme birimleri olan ad ve sıfatların sıklık, dağılım ve birleşimlerinin, metnin üslubu hakkında belirleyici olabildikleri gözlenmiştir. Seçmeli dil değişkenlikleri gösteren bu dil birimlerinin sıklık ve yoğunluklarının, üslup tasvirine ve yorumuna malzeme oluşturduğu gözlenmiştir.

Yazarın kişisel dil kullanımı / üslubu belirlenirken adlarda özel ve cins ayrımına dikkat edilmesi gerektiği görülmektedir. Yazarın özel adları seçerken canlı kahramanlara gönderme yapan kişi adlarına yoğunluk vermesi dikkat çekicidir. Metnin büyük bir bölümünü oluşturan cins adlarınsa çok kritik görevler üstlendiği, öbeklendikleri bazı kavram alanları aracılıklarıyla metnin anlatım bütününe doğrudan etki ettikleri görülmektedir. Özellikle mekân / yer / yön kavram alanına giren cins adlar, organ ve vücut bölümü adları, akrabalık adları, araç / gereç adları, cinayet / ölüm, parasal değerler ve sorgulama / araştırma kavram alanına giren adların öne çıktıkları ve metnin bu kavramlar etrafında biçimlendiği söylenebilir. Yazarın dünyayı algılayış tarzı, okuyucunun gözünde canlandırmak istediği sahneler ve betimlemeler bu 
sözcüklerin etrafında sunulmuştur. Adlarda çoğulluk, soyutluk ve somutluk ilişkilerinin de bu eğilimi desteklediği gözlenmiş̧tir.

Sıfatlardaysa niteleme ve belirtme (gösterme) şeklinde ikili ayrımın altı belirgin bir biçimde çizilmiştir. Bunların arasında öne çıkanın anlatıma nasıl katkı sağladığı, birbirleriyle aralarındaki tamamlayıcı ya da ayırıcı ilişkilerin kişisel dil kullanımına nasıl yansıdığının üslup oluşumunda oldukça önemli olduğu görülmüştür. İnceleme ve bulgular kısmında niteleme sıfatlarına yoğunluk verildiği bunun da yazarın gözlem ve betimlemeleri cins adlardaki gibi belirli kavram alanlarına ait niteleme bildiren sıfatlarla gerçekleştirdiği sonucuna varılabilir. İş, oluş ve hareket bildirme, mekân / yer / yön algısına yönelik olma ve dış görünüş, beden yapısı ve fiziksel özellik bildirme gibi özellikler metnin anlatım bütününe ve okuyucuda oluşturulması hedeflenen algıya çeşitli açılardan katkıda bulunmaktadır. Belirsizlik, işaret ve sayı gösteren belirtme sıfatlarındaki seçimlerin de yazarın, okuyucunun zihninde kimi zaman sınırlar koymaya çalıştığı kimi zaman da geniş düşünce çağrışımlarına firsat tanıdığını göstermektedir.

Sonuç olarak, elde edilen bulgular ve üretilen yorumlar, yazarın kişisel dil seçimlerinin diğer inceleme düzlemlerinde de kolaylıkla kendini belli edeceğinin işaretlerini vermektedir. Yöntem bölümünde söz edildiği gibi bu çalışmanın ikincisinde zarflar, bağlaçlar, edatlar, ünlemler ve eylemler aynı metin üzerinde üslup belirleyicilik açısından incelenecektir. Böylelikle az ya da çok her sözcüksel dil biriminin belli bir düzeyde üslup özelliği yansıttığı kanıtlanmaya çalışılacaktır.

\section{Kaynaklar}

ALAGÖZLÜ, N. (2005). Yılmaz Erdoğan'ın 'Keşke' Öyküsü ve Söylem Biçembilimi: Bir Yöntem ve Uygulama. Journal of Language and Linguistic Studies, 1(1), 67-80.

ATABAY, N, ÖZEL, S. ve KUTLUK, İ. (2003). Sözcük Türleri. İstanbul: Papatya Yayıncılık.

AYTAÇ, G. (2009). Genel Edebiyat Bilimi, İstanbul: Say Yayınları.

BÖREKÇİ, M. ve TEPELİ, Y. (1996). Tarık Buğra'nın ‘Ömer' Adlı Hikâyesinin Dil ve Üslup Açısından Tahlili. Atatürk Üniversitesi Türkiyat Araştırmaları Enstitüsü Dergisi, 6, 2966.

BULAK, Ş. (2016). Bir Mikro Üslup İnceleme Denemesi: Ahmed Arif'in Merhaba, İçerde, Ay Karanlık Şiirlerinde Üslup. Atatürk Üniversitesi Türkiyat Araştırmaları Enstitüsü Dergisi, 55, 277-304.

DELİCE, H. İ. (2012). Sözcük Türleri. Sivas: Asitan Yayınc1l1k.

ERGİN, M. (2006). Türk Dil Bilgisi. İstanbul: Bayrak Basım / Yayım / Dağıtım.

GÖZ, İ. (2003), Yazılı Türkçenin Kelime Sıklı̆̆ı Sözlügü. Ankara: Türk Dil Kurumu Yayınları.

GÜNDOĞDU, A. E. (2012). Haldun Taner'in Konçinalar Adlı Öyküsünün Biçembilimsel Açıdan İncelenmesi. Adıyaman Üniversitesi Sosyal Bilimler Enstitüsü Dergisi, 8, 40-50. 
GÜNEY, Z. (2003). Üslup Özellikleri Açısından Berci Kristin Çöp Masalları. Folklor / Edebiyat, 19(73), 23-48.

KARAAĞAÇ, G. (2012). Türkçenin Dil Bilgisi. Ankara: Akçağ Yayınları.

KORKMAZ, Z. (2009). Türkiye Türkçesi Grameri Şekil Bilgisi. Ankara: Türk Dil Kurumu Yayınları.

SARIBAŞ, T. (2001). Nesnellik Öznellik İkileminde Biçembilim ve Düzyazı Çözümlemesi için Bir Yöntem: Sabahattin Ali’nin 'Kağnı' Adlı Öyküsü’. Dilbilim ve Uygulamaları, 2, 81-95.

ÜLSEVER, Ş. (2005). Feminist Söylem Çerçevesinde Nazlı Eray'ın Öykülerinin Biçemsel Çözümlemesi: Bir Uygulama. IV. Uluslararası Dil, Yazın ve Deyişbilim Sempozyumu Bildirileri, Çanakkale: Nobel Yayın Dağıtım, 329-335.

ÜSTÜNOVA, K. (2010). Sözcük Türü Görev Adı Ayrımı. Dil Bilgisi Sorunları, İstanbul: Kesit Yayınları, 157-162.

ÜSTÜNOVA, K. (2011). Eksilti ya da Sıfır Tekrar. Dil Yazıları, Ankara: Akçağ Yayınları, 124134.

ÜSTÜNOVA, K. (2012). Türkiye Türkçesi Ad İşletimi (Biçim Bilgisi). Ankara: Sentez Yayınc1lik.

YELOK, V. S. (2008). Erkin Vâhidov'un Kelime Dünyasına Bir Bakış. Uluslararası Sosyal Araştırmalar Dergisi, 1(3), 442-470.

YILDIZ, C. (2003). Üslup İncelemesinde Ortak Yaklaşım Arayışı ve Bir Tahlil Denemesi. III. Dil, Yazın ve Deyişbilim Sempozyumu Bildirileri, Eskişehir: Birlik Ofset, 567-589. 